\title{
Ethnobotanical Study of the Traditional Use and maintenance of Medicinal Plants by the People of Aleta-Chuko Woreda, South Ethiopia
}

\author{
Tizazu Gebre, Bhaskarrao Chinthapalli*
}

Tizazu Gebre, Bhaskarrao Chinthapalli*

Department of Biology, College of Natural Sciences, Arba Minch University, P.O. Box 21, Arba Minch, ETHIOPIA.

\section{Correspondence}

Chinthapalli Bhaskar Rao

Department of Biology, College of Natural Sciences, Arba Minch University, P.O. Box 21, Arba Minch, ETHIOPIA.

E-mail: chinthapalli.bhaskar@amu.edu.et History

- Submission Date: 21-04-2021;

- Review completed: 03-06-2021;

- Accepted Date: 18-06-2021.

DOI : 10.5530/pj.2021.13.142

Article Available online

http://www.phcogj.com/v13/i5

Copyright

(C) 2021 Phcogj.Com. This is an openaccess article distributed under the terms of the Creative Commons Attribution 4.0 International license.

\begin{abstract}
Background: Over centuries, indigenous people have developed their own locality specific knowledge on plant use, management and conservation. However, this valuable traditional knowledge on utilization of plants was not much documented and hence, most of the indigenous knowledge acquired by the local people has been passed on from generation to generation by the word of mouth. Ethnobotanical study is of the use and maintenance of traditional medicinal plant species by the people of Aleta Chuko woreda, South Ethiopia. The study made an attempt to assess the indigenous knowledge that equips the community to identify the medicinal plants, formulate the medicines and subsequently administer the curatives used to treat various human and livestock diseases as the threats that could affect their sustainable use. Methods: A total of 100 informants ( 85 males and 15 females) were selected to collect information on medicinal plant use from five selected kebeles by using non-probability sampling method. Relevant ethnobotanical information was collected through semi-structured interview, field observation and group discussion. Data was analyzed using descriptive statistics and simple linear correlation coefficient. The study was carried out from September, 2017 to July, 2018. Results A total of 53 medicinal plant species representing 49 genera and 30 plant families used in the treatment of 92 ( 81 human and 11 livestock) different ailments. The plant families Lamiaceae, Rutaceae, and Asteraceae were the most dominant groups. Out of the total recorded medicinal plant species, $79 \%, 11 \%$ and $10 \%$, were used for treating human, livestock and both humans and livestock health problems respectively. Stomachache and cough were the most common health problems of the study area affecting both humans and animals. $60 \%$ of the medicinal plant species were collected from the wild/forest and the remaining $40 \%$ were collected from the Homegardens. Herbs were the dominant medicinal plant habit, followed by shrubs and trees. Leaves are the dominant plant part used in formulating curative preparations. The most dominant methods of preparation were crushing and pounding and $70.5 \%$ is the dominant route of oral administration. Fagaropsis angolensis was the most effective curatives species against stomach ache, the most common human disease in the study area, followed by Leonotis nepetifolia, and Ajuga integrifolia, Ocimum lamiifolium was the most preferred medicinal plant to treat headache followed by Echinops kebericho and Salvia nilotica. Conclusions: The Coffee-Enset based home gardens which characterize the study area make a substantial contribution to the conservation of medicinal plants species. In order to conserve the traditional medicinal plant species of the study area, community-based in-situ and ex-situ conservation actions, awareness creation in the younger members, and strengthening home gardens and other components of the agro-forestry systems to be used as repositories of medicinal plant species and alternative conservation sites are recommended. Key words: Ethnobotany, Indigenous knowledge, Traditional healers, Medicinal plant species.
\end{abstract}

\section{INTRODUCTION}

Over centuries, indigenous people have developed their own locality specific knowledge on plant use, management and conservation. ${ }^{1}$ Therefore, the conservation of ethnobotanical knowledge became a part of living cultural knowledge and practices between communities and the environment which is essential for biodiversity conservation. ${ }^{2,3}$ However, this valuable traditional knowledge on utilization of plants was not documented and hence, most of the indigenous knowledge acquired by the local people has been passed on from generation to generation by the word of mouth. ${ }^{4-6}$ Such orally preserved information is liable to loss rather than conserved for future use, if left undocumented and in most cases some of the lore is lost at each point of transfer. ${ }^{2}$ According to world Health Organization those traditional medicinal plants were believed principally by more than $80 \%$ of the population in Africa. ${ }^{7}$ Hence, the need for systematic documentation of such a useful knowledge is nowadays accomplished through ethnobotanical research. ${ }^{1,2,8}$

Although Ethiopia is endowed with multiethnic cultural diversity that has evolved within the milieus of diverse flora, medicinal plants have not been adequately studied, tested or documented. ${ }^{9}$ As a result, much of the traditional medicinal plant resources and the associated knowledge has not been much documented and hence face the threat of erosion and loss. The Aleta Wondo people, like many other traditional groups of Ethiopia, practice traditional medicine to treat both human and livestock ailments, and acquired knowledge accumulated over centuries. This study therefore aims to investigate plant based traditional medicinal practices among the people of the study area by focusing on communities living in Aleta-Chuko Woreda of Sidama Zone, South Ethiopia. The purpose of this study is to document traditional

Cite this article: Gebre T, Chinthapalli B. Ethnobotanical Study of the Traditional Use and maintenance of Medicinal Plants by the People of Aleta-Chuko Woreda, South Ethiopia. Pharmacogn J. 2021;13(5): 1097-1108. 
medicinal plants species, management practices and the associated indigenous knowledge of the people in Aleta-Chuko Woreda, and to identify the major threats against these plants species in the study area.

\section{METHODS}

\section{The Study Area}

The study was conducted in Aleta-Chuko Woreda, South Ethiopia, from October 2017 to May 2018. Aleta-Chuko Woreda is located in Sidama Zone, Southern Nation Nationalities people Regional State. Relative location: Aleta Chuko is bordered on the south by Dara, on the southwest by the Oromia Region, on the west by Lake Abaya, on the north by Dale, and on the east by Aleta Wendo (Figure 1). The administrative center is Chuko. Chuko was separated from Aleta Wendo woreda II. Aleta Chuko, in an absolute location, is found within 6460'- 6720' N Latitude and 3820'-3856' E Longitude. The Woreda is situated $338 \mathrm{~km}$ south of Addis Ababa. The Woreda has an estimated area of $91,750.2$ ha and it consists of 28 Kebeles..$^{10,11}$

\section{Sampling and data collection}

Prior to the start of the actual study, a reconnaissance observation was carried out within the Aleta-Chuko Woreda to identify potential study sites, and ultimately decide on those deemed suitable for the objective of the present study. Selection of the Kebeles were based on the number (and/or distribution) of traditional healers within each Kebele of the study Woreda. Informants and knowledgeable traditional medicine practitioners were selected using purposive sampling approaches in the manner described by. ${ }^{2} 100$ Respondents ( 85 males and 15 females; 20 Respondents from each of the 5 Kebeles) were selected in order to generate information through interviews and group discussions. The traditional healers were formally nominated by elders, local authorities, development agents and local Administrators.

Semi-structured interviews, focus group discussions and field observation were used to collect ethnobotanical data. Informants were interviewed individually in their local language, Sidamuu Affoo. Semi-structured interviews (SSI) were used to collect data on personal profiles of informants, as well as all necessary information on traditional medicinal plant species (e.g. ailments treated, parts used, etc.). Voucher Specimens were collected following the standard herbarium procedures and identifications were carried out using personal expertise and experience as well as using the published books series of different volumes (Volumes 1 to 7 ) of the Flora of Ethiopia and Eritrea. ${ }^{12-20}$

\section{Data Analysis}

The quantitative data were analyzed using descriptive statistics and results were displayed by tables and graphs. Informant consensus, use value/relative importance and informant consensus factor were also computed. Simple linear correlation test was performed to assess the association between medicinal plant knowledge and age of informants as well as between medicinal plant knowledge and educational background of informants. Moreover, ranking and comparison techniques were also employed.

\section{RESULTS AND DISCUSSION}

\section{Informants' profile}

Out of the 100 respondents interviewed in the study area, 85 were belong to male category and the remaining 15 respondents were female category. As far as the sex category of the respondents are concerned, the males are high number compare with females. It is primarily due to cultural influence prevailing in Aleta Chuko Woreda, where women were very much reluctant to meet the outsiders and hence, this, at least in part, accounts for the limited participation of the same during the study. Likewise, in similar studies ${ }^{21,22}$, males accounted for comparatively higher proportions out of the total respondents.

The age category $\geq 60$ constituted the highest percentage (29\%), followed by $50-59(24 \%)$ and $40-49(22 \%)$. On the contrary, the age groups $20-29$ and 30-39 were represented by the lowest number of respondents (Table 1). Nonetheless, the size of every category of age corresponds to considerable fraction $(\geq 11 \%)$ of the total number of respondents. Comparable distribution of informants in age categories was conducted by ${ }^{23}$, in his ethnobotanical investigation of Konta special woreda, SNNPRS, Ethiopia.

As regards to educational background, the majority (59\%) of the respondents were illiterate, while $33 \%, 5 \%$, and $3 \%$ of the informants had primary, secondary and above secondary education respectively. Although most of the participants were illiterate which coincided mainly with age group above 40 , they are generally considered as important repository of traditional medicinal knowledge (Table 1).

Distribution, Diversity and Therapeutic Worths of Medicinal Plants in the Studyarea

A total number of 53 medicinal plant species distributed over 30 plant families and 49 genera, were recorded in this study in Aleta Chuko Woreda. Among these plant families, Lamiaceae represented by the highest species (8) followed by Rutaceae (5), Asteraceae (4), Rosaceae (3), Fabaceae (3) and Solanaceae (3). While Myrtaceae, Oleaceae, and Boraginaceae had two species each, the remaining 21 families were represented by single species (Table 2). ${ }^{24}$, also reported that the family Lamiaceae had highest number of species represented by (19). Similarly, ${ }^{23}$ reported that Lamiaceae and Asteraceae were the second and third most important families containing high number of medicinal plant species in Konta special woreda, SNNPRS, Ethiopia. ${ }^{25}$, in his appraisal on the indigenous knowledge of medicinal plants use in Hawassa City, indicated that Lamiaceae, Rutaceae, and Asteraceae were among the families that contributed more to the medicinal species. Whereas ${ }^{26}$, reported Fabaceae, Rosaceae, and Solanaceae were among the important families of medicinal plant species. This essentially suggests that there is wider utilization of the top six families in the present study (Lamiaceae, Rutaceae, Asteraceae, Fabaceae, Rosaceae, and Solanaceae) for medicinal purpose by diverse communities across the different corners of Ethiopia, which eventually can substantiate their efficacy levels. The consumption of such a large number of medicinal plants by people in the study area indicates that the majority of the local people is still employing and possibly may continue to use indigenous

Table 1: Background of Respondents ( $n=100)$.

\begin{tabular}{lcc}
\hline Variables & Frequency & Percentage (\%) \\
Sex & & \\
Male (M & 85 & 85 \\
Female (F) & 15 & 15 \\
Age Category & 11 & 11 \\
$20-29$ & 14 & 14 \\
$30-39$ & 22 & 22 \\
$40-49$ & 24 & 24 \\
$50-59$ & 29 & 29 \\
$\geq 60$ & & \\
Educational Background & 59 & 59 \\
Illiterates & 17 & 17 \\
Primary (First cycle (1-4 grade)) & 16 & 16 \\
Primary (Second Cycle (5-8 grade) & 5 & 5 \\
Secondary High School (9-10 grade) & 3 & 3 \\
Above grade $10\left(>10^{\text {th }}\right.$ ) & &
\end{tabular}


knowledge on medicinal practices for their therapeutic effects against different ailments in the study area.

\section{Medicinal plant species used for humans, livestock and both health problems}

Out of the total 53 medicinal plant species recorded in this study, the majority (79\%) of medicinal plant species were used to treat 81 human diseases, while $11 \%$ of the same were used to treat 11 livestock ailments and $10 \%$ for both (Figure 2 and Table 3).

In line with the present study, a number of studies ${ }^{23,25,27-31}$, reported that most of the medicinal plants are commonly used for the treatment of human ailments than therapeutic applications of medicinal plants that are intended to relieve illness or injury of livestock.

\section{Health problems identified in the study area}

On the other hand, the most common Human and Livestock Diseases in Aleta Chuko Woreda are indicated in Table 4. The most common human ailment was Stomachache followed by headache, wound, and common cold. Conversely, important livestock diseases reported in the study area are cough, poor milk yield, and stomachache (Table 4). As ${ }^{30}$, pointed out that the traditional healers in the study area were knowledgeable of diseases and medicinal plants used to treat them.

\section{Source habitats of traditional medicinal plant species}

The majority i.e., 32 (60\%) of the medicinal plant species were collected from the wild (natural and semi-natural habitats), whereas the remaining 21 (40\%) were collected from home-gardens. Our study was found to have similarity with ${ }^{21,25,27,32,33}$, which showed that medicinal plants were commonly collected from the natural habitats. The high number of natural environment medicinal plant species collection from natural or wild habitats may indicate that there is little or no attempt to conserve or deliberately cultivate by the traditional healers. Consequently, local practitioners of the study area have to considerably rely on the wild source or the natural environment rather than Home gardens to obtain the medicinal plants and hence, the activity of managing wild medicinal plants is ineffectual. According to ${ }^{27}$ and $^{34}$, local practitioners depend on the wild source of medicinal plants and hence, the activity of managing and conserving natural environments medicinal plants in a particular area is not easy, especially if the plants are over exploited.

\section{Habits of the medicinal plants}

The assessment on the habits of the medicinal plants depicted that Herbs constituted the highest fraction (34\%) of the total species collected closely followed by both Shrubs and Trees (32\%). Conversely, climbers accounted for only a tiny fraction $(2 \%)$ of medicinal plants assayed under the present study (Figure 3). Saving climbers ${ }^{35}$, reported comparable fractions of herbs (37\%), trees (32\%) and shrubs $(31 \%)$ in his study of medicinal plants from Ghimbi District, Southwest Ethiopia. Evidently, the present data suggested that herbs are still considered as the most important source of therapeutics for the treatment of both Human and Livestock ailments. In line with the present data, various studies ${ }^{21,25,26,28,30,35-37}$, found that Herbs were the most harvested plant forms for the treatment of diseases of humans and their stocks. The key informants as well as the traditional healers revealed that collection of medicinal plants usually carried out during rainy season. On the other hand, it is worth noting that the shrubs and trees are also key contributors towards the traditional Ethnomedicine and Ethnoveterinary practices of the Aleta Chuko Woreda. It may also be noted that the woody plants could serve as important sources of curatives even during both wet and dry seasons.

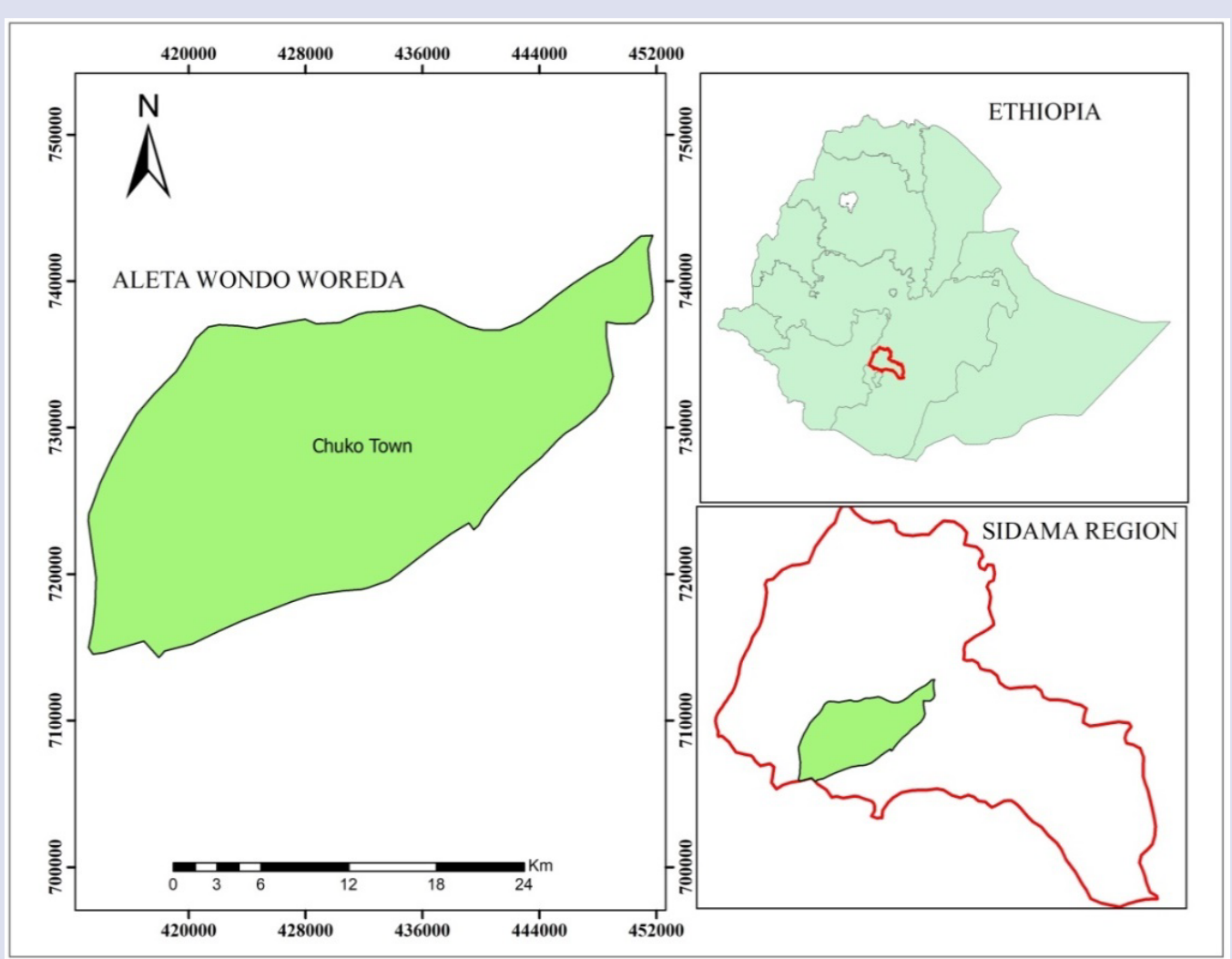

Figure 1: Map of the study area. Location of Alete Chudo Woreda Zone in Sidama Area, Ethiopia. Data Source: Ethio-GIS collected by ECSA (Ethiopian Central Statistics Authority, 2014), Software Arch-GIS 9.2 used. 
Table 2: Distribution of the Medicinal Plant species among the plant families and percentage.

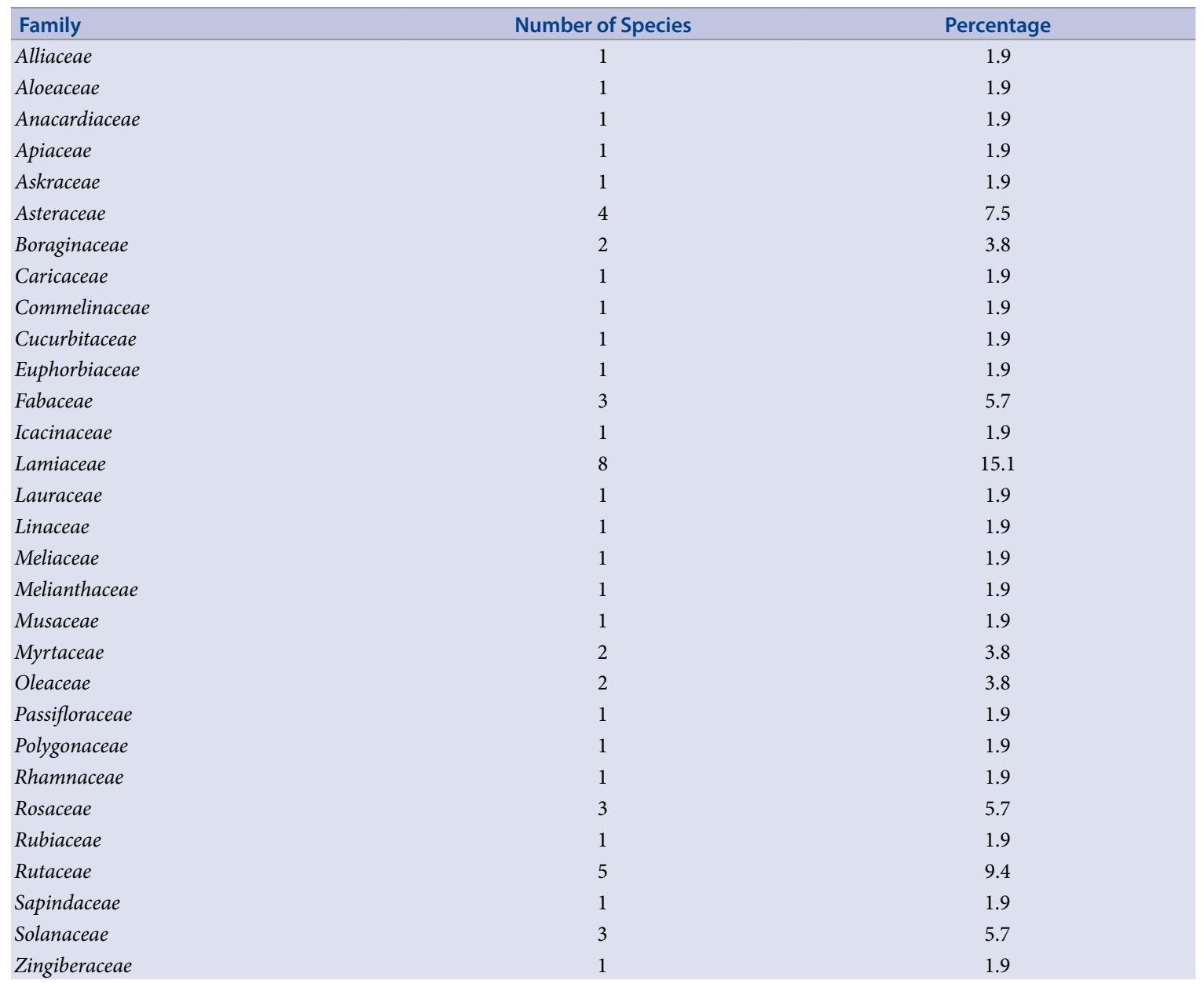

Table 3: List of Medicinal Plants used for the Treatment of Human and Livestock Ailments in the Study Area. GH=growth habit, Part Used=PU, H=herb, S=shrub, L=leaf, B=bark, R=root, St=stem, Fl=flower, Flr=flower\&root, Sd=seed, L\&Sd=leaf and seed Bb=bulb, StR=stem \& root, Ft=fruit, Route= Route of administration.

\begin{tabular}{|c|c|c|c|c|c|c|c|}
\hline Botanical/Scientific Name & Local Name & Plant Family Name & GH & PU & Preparation Method & Route & Disease Treated \\
\hline $\begin{array}{l}\text { Chyrospermum shinger } \\
\text { (Hochst ex Briq.) }\end{array}$ & Bulancho & Lamiaceae & $\mathrm{H}$ & $\mathrm{L}$ & Crushing fresh Leaf to get the juice & Oral & Liver (human) \\
\hline Ehretia cymosa Thonn. & Gidincho & Boraginaceae & $\mathrm{S}$ & $\begin{array}{l}\mathrm{L} \\
\mathrm{B}\end{array}$ & $\begin{array}{l}\text { Fresh Leaf Extract } \\
\text { Decoction }\end{array}$ & Oral & $\begin{array}{l}\text { Liver (Human), Tuberculosis, } \\
\text { Stomachache (Livestock) }\end{array}$ \\
\hline Passiflora edulis Sims. & Hopicho & Passifloraceae & $\mathrm{C}$ & $\mathrm{L}$ & To chew and swallow the juice & Oral & Hypertension \\
\hline $\begin{array}{l}\text { Pyscnostachys abyssinica } \\
\text { Fresen. }\end{array}$ & Malasincho & Askraceae & S & $\mathrm{R}$ & Decoction & Oral & Lumpy Skin Disease \\
\hline $\begin{array}{l}\text { Olea capensis subsp. } \\
\text { macrocarpa }\end{array}$ & Setamo & Oleaceae & $\mathrm{T}$ & $\mathrm{R}$ & $\begin{array}{l}\text { Chew the Root in order to let the sap } \\
\text { drip on the affected tooth }\end{array}$ & Oral & Toothache (human) \\
\hline \multirow{3}{*}{ Croton macrostachyus Del. } & \multirow{3}{*}{ Masincho } & \multirow{3}{*}{ Euphorbiaceae } & \multirow{3}{*}{$\mathrm{T}$} & \multirow{3}{*}{$\mathrm{L}$} & \multirow[t]{2}{*}{ Topical application of the sap } & Dermal & $\begin{array}{l}\text { Wounds ( } 2^{\circ} \text { Skin Infection) } \\
\text { (human) }\end{array}$ \\
\hline & & & & & & Dermal & Chirt \\
\hline & & & & & $\begin{array}{l}\text { Grind the leaves and mix the same } \\
\text { with water and butter and filter. }\end{array}$ & Oral & Malaria, Gonorrhea (human) \\
\hline Vernonia amygdalina Del. & Hecho & Asteraceae & $\mathrm{T}$ & $\mathrm{R}$ & $\begin{array}{l}\text { The root is crushed and pound along } \\
\text { with the leaves of } C \text {. macrostachyus } \\
\text { and } E \text {. cymosa. The water is added } \\
\text { to the pounded stuff and the filtrate } \\
\text { is drunk. }\end{array}$ & Oral & $\begin{array}{l}\text { Coughing, Retained Placenta } \\
\text { (Livestock) }\end{array}$ \\
\hline $\begin{array}{l}\text { Ocimum urticifolium Roth } \\
\text { S. Lat. }\end{array}$ & Damakase & Lamiaceae & S & $\mathrm{L}$ & Fresh Leaf Extract & Oral & Allergy, Headache (human) \\
\hline \multirow[t]{2}{*}{ Ocimum lamiifolium } & \multirow[t]{2}{*}{ Damakase } & \multirow[t]{2}{*}{ Lamiaceae } & \multirow[t]{2}{*}{ S } & \multirow[t]{2}{*}{$\mathrm{L}$} & $\begin{array}{l}\text { Pound the leaves and extract the } \\
\text { juice }\end{array}$ & Oral & $\begin{array}{l}\text { Diarrhea, Poor Appetite, } \\
\text { Flatulence (both human and } \\
\text { livestock) }\end{array}$ \\
\hline & & & & & Inhalant prepared by smashing & Nasal & Headache (human) \\
\hline
\end{tabular}




\begin{tabular}{|c|c|c|c|c|c|c|c|}
\hline Ajuga integrifolia D Don. & Anamuro & Lamiaceae & $\mathrm{H}$ & $\mathrm{L}$ & $\begin{array}{l}\text { The extracted juice is mixed with } \\
\text { water or milk }\end{array}$ & Oral & $\begin{array}{l}\text { Stomachache (both human } \\
\text { and livestock) }\end{array}$ \\
\hline Commelina benghalensis $\mathrm{L}$. & Lalunte & Commelinaceae & $\mathrm{H}$ & St & Sap extracted from the Stem & Dermal & (Chirt) (human) \\
\hline \multirow{2}{*}{$\begin{array}{l}\text { Leonotis nepetifolia (L.) } \\
\text { R. Br. }\end{array}$} & \multirow[t]{2}{*}{ Bokola } & \multirow[t]{2}{*}{ Lamiaceae } & \multirow[t]{2}{*}{$\mathrm{S}$} & $\mathrm{L}$ & Leaf extract & Oral & $\begin{array}{l}\text { Headache, Allergy (both } \\
\text { human and livestock) }\end{array}$ \\
\hline & & & & Fl r & Chewing the Flower & Oral & Stomachache \\
\hline \multirow{2}{*}{$\begin{array}{l}\text { Dichrocephala integrifolia } \\
\text { (Lifio) Kuntze }\end{array}$} & \multirow[t]{2}{*}{ Dinbilal } & \multirow[t]{2}{*}{ Asteraceae } & \multirow[t]{2}{*}{ S } & \multirow[t]{2}{*}{ Fl } & \multirow{2}{*}{$\begin{array}{l}\text { Extract fluid from the Flower by } \\
\text { squeezing }\end{array}$} & Oral & $\begin{array}{l}\text { Headache (both human and } \\
\text { livestock) }\end{array}$ \\
\hline & & & & & & Dermal & Skin Allergy \\
\hline Ocimum lamifolium & $\begin{array}{l}\text { Yewisha } \\
\text { Damekese }\end{array}$ & Lamiaceae & S & $\mathrm{L}$ & $\begin{array}{l}\text { Leaves are squeezed to extract the } \\
\text { juice }\end{array}$ & Oral & $\begin{array}{l}\text { Headache, } \\
\text { Stomachache (human) }\end{array}$ \\
\hline $\begin{array}{l}\text { Cynoglassum cooruleum } \\
\text { Steud. Ex DC }\end{array}$ & Bartatusa & Boraginaceae & & $\mathrm{L}$ & $\begin{array}{l}\text { Leaves are squeezed and the juice } \\
\text { mixed with Coffee }\end{array}$ & Oral & Headache (human) \\
\hline \multirow{2}{*}{ Salvia nilotica } & \multirow{2}{*}{ Hulgeb } & \multirow{2}{*}{ Lamiaceae } & \multirow{2}{*}{ S } & \multirow{2}{*}{$\mathrm{L}$} & $\begin{array}{l}\text { Leaves are squeezed and the juice } \\
\text { mixed with Coffee }\end{array}$ & Oral & Headache (human) \\
\hline & & & & & $\begin{array}{l}\text { Rubbing the affected area with the } \\
\text { leaf extract/juice }\end{array}$ & Dermal & $\begin{array}{l}\text { Wound (both human and } \\
\text { livestock) }\end{array}$ \\
\hline \multirow{4}{*}{$\begin{array}{l}\text { Apodytes dimidiata } \\
\text { E. Mey. Ex. Benth }\end{array}$} & \multirow{3}{*}{ Dongicho } & \multirow{3}{*}{ Icacinaceae } & \multirow{3}{*}{$\mathrm{T}$} & St & $\begin{array}{l}\text { Debark the Twigs and pound. The } \\
\text { water is then added to the crushed } \\
\text { twigs }\end{array}$ & \multirow{3}{*}{ Oral } & Cough (Livestock) \\
\hline & & & & $\mathrm{L}$ & $\begin{array}{l}\text { Leaves are pound and mixed with } \\
\text { water }\end{array}$ & & Poor Milk Yield (Livestock) \\
\hline & & & & $\mathrm{L}$ & Decoction made with Tea & & Blood Pressure (Humans) \\
\hline & Godicho & Rutaceae & $\mathrm{T}$ & Sd & $\begin{array}{l}\text { Chewing the Seeds and swallowing } \\
\text { the juice-for humans } \\
\text { Crush the seeds and then add water } \\
\text { to it-for livestock }\end{array}$ & Oral & Stomachache (Human) \\
\hline $\begin{array}{l}\text { Syzygium guineense (Willd.) } \\
\text { DC. }\end{array}$ & Duwancho & Myrtaceae & $\mathrm{T}$ & St & $\begin{array}{l}\text { Crushed and homogenized in water } \\
\text { to drink }\end{array}$ & Oral & Low Milk Yield (livestock) \\
\hline \multirow{3}{*}{ Rubus steudneri. } & \multirow{3}{*}{ Gadda } & \multirow{3}{*}{ Rosaceae } & \multirow{3}{*}{$\mathrm{T}$} & $\mathrm{L}$ & $\begin{array}{l}\text { The fresh leaves are chewed and its } \\
\text { juice is left to drip and later spit-for } \\
\text { humans (toothache) }\end{array}$ & Oral & Toothache (Human) \\
\hline & & & & L\&Sd & $\begin{array}{l}\text { The same as above but the juice is } \\
\text { drunk }\end{array}$ & Oral & $\begin{array}{l}\text { Rheumatic (Human) } \\
\text { Pain }\end{array}$ \\
\hline & & & & Sd & $\begin{array}{l}\text { Mixing the powder with water and } \\
\text { drinking the filtrate-for humans } \\
\text { and livestock }\end{array}$ & Oral & $\begin{array}{l}\text { Aqim asatito yemiyangedagid } \\
\text { beshita (Livestock) } \\
\text { Physical deterioration? }\end{array}$ \\
\hline \multirow[t]{2}{*}{$\begin{array}{l}\text { Albizia gummifera } \\
\text { (J. F. Gamel.) C. A. Sm. }\end{array}$} & \multirow[t]{2}{*}{ Matticho } & Fabaceae & $\mathrm{T}$ & St & $\begin{array}{l}\text { Debark the Twigs and pound. The } \\
\text { water is then added to the crushed } \\
\text { twigs }\end{array}$ & Oral & Low Milk Yield (Livestock) \\
\hline & & & & & $\begin{array}{l}\text { Chew the fresh leaves and swallow } \\
\text { the juice }\end{array}$ & Oral & \\
\hline Rosa abyssinica Lindl. & Gao & Rosaceae & $\mathrm{S}$ & $\mathrm{L}$ & $\begin{array}{l}\text { Crush the leaves and mix it with } \\
\text { water and the filtrate is given to the } \\
\text { sick stock }\end{array}$ & Oral & Stomachache (Human) \\
\hline Olea europaea subsp. & & & & & $\begin{array}{l}\text { Chew the fresh leaves with the } \\
\text { aching tooth }\end{array}$ & Oral & Toothache (Human) \\
\hline cuspidata & Ejersa & Oleaceae & 1 & $\mathrm{~L}$ & $\begin{array}{l}\text { Crush the leaves and apply the sap } \\
\text { on the diseased eye/s }\end{array}$ & Ocular & Ophthalmia (Human) \\
\hline $\begin{array}{l}\text { Ekebergia capensis } \\
\text { Sparrman }\end{array}$ & Oloncho & Meliaceae & $\mathrm{T}$ & St & $\begin{array}{l}\text { Pound the Twigs and the water } \\
\text { added to get the infusion }\end{array}$ & Oral & Cough (Human) \\
\hline Teclea nobilis Del. & Hadessa & Rutaceae & $\mathrm{T}$ & $\mathrm{L}$ & $\begin{array}{l}\text { The juice is mixed with water and } \\
\text { drunk }\end{array}$ & Oral & $\begin{array}{l}\text { Stomachache, Gastritis } \\
\text { (Human) }\end{array}$ \\
\hline Dodonaea angustifolia L. F. & Itancha & Sapindaceae & S & $\mathrm{L}$ & $\begin{array}{l}\text { Fresh leaves are pounded and juice } \\
\text { prepared }\end{array}$ & Oral & Helminthiasis (Human) \\
\hline & Buna & & & & The roasted and ground powder & Oral & Diarrhea (Human) \\
\hline Coffea arabica L. & Buna & Rubiaceae & $\mathrm{S}$ & $\mathrm{L}$ & mixed with Honey & Topical & Wound (Human) \\
\hline Zingiber officinale & Janjibelo & Zingiberaceae & $\mathrm{H}$ & $\mathrm{R}$ & $\begin{array}{l}\text { Remove the epidermis, crush then } \\
\text { boil and serve it with sugar }\end{array}$ & Oral & $\begin{array}{l}\text { Common Cold; } \\
\text { Influenza (Human) }\end{array}$ \\
\hline & & & & & & Oral & Blackleg (Livestock) \\
\hline Allium sativum $\mathrm{L}$. & Tuma/ Wajo & Alliaceae & $\mathrm{H}$ & $\mathrm{Bb}$ & Cloves of Garlic and Ginger pound & Topical & Dermatophilosis (Livestock) \\
\hline Altum sulvam L. & Shunkurte & Rimacede & & & up and mixed with honey & Topical & Skin problems (Livestock) \\
\hline & & & & & & Nasal & Leech (Livestock) \\
\hline
\end{tabular}




\begin{tabular}{|c|c|c|c|c|c|c|c|}
\hline Echinops kebericho Mesfin & Qabaricho & Asteraceae & $\mathrm{H}$ & $\mathrm{R}$ & Smoking the root to get the inhalant & Nasal & $\begin{array}{l}\text { Headache, Common Cold, } \\
\text { Influenza, (Human) }\end{array}$ \\
\hline \multirow{2}{*}{$\begin{array}{l}\text { Nicotiana tabacum } \\
\text { L. }\end{array}$} & \multirow[t]{2}{*}{ Arado } & \multirow[t]{2}{*}{ Solanaceae } & \multirow[t]{2}{*}{ s } & \multirow[t]{2}{*}{$\mathrm{L}$} & $\begin{array}{l}\text { Dry leaves are ground and powdered } \\
\text { then drunk for } \\
\text { Livestock }\end{array}$ & Oral & $\begin{array}{l}\text { Common cold (Human) } \\
\text { (Livestock) }\end{array}$ \\
\hline & & & & & $\begin{array}{l}\text { Inhaling the powder through nose } \\
\text { for Humans }\end{array}$ & Nasal & Headache (Human) \\
\hline \multirow{3}{*}{ Aloe vera } & \multirow{3}{*}{ Erret } & \multirow{4}{*}{ Aloeaceae } & \multirow{3}{*}{$\mathrm{H}$} & \multirow{3}{*}{$\mathrm{L}$} & $\begin{array}{l}\text { Mix } 1 \text { tablespoon of pulp with honey, } \\
\text { eaten } 2 \text { times a day } \\
\text { spikes removed, pound with some } \\
\text { water to make pulp }\end{array}$ & Leaves & Cancer and Laxative (Human) \\
\hline & & & & & Apply liquid from pulp to wound & Dermal & Wound healing (Human) \\
\hline & & & & & $\begin{array}{l}\text { Massage pulp into scalp, sit under } \\
\text { sun for } 30 \mathrm{~min} \text {, wash hair }\end{array}$ & Topical & Dandruff (Human) \\
\hline \multirow{3}{*}{ Artemisia absinthium } & \multirow{3}{*}{ Inare } & & \multirow{3}{*}{$\mathrm{H}$} & \multirow{3}{*}{$\mathrm{L}$} & Crushed leaves and apply topically & Topical & Chicken Pox (Human) \\
\hline & & \multirow[t]{2}{*}{ Asteraceae } & & & $\begin{array}{l}\text { Wrap leaves in Enset leaves and } \\
\text { put over fire, squeeze liquid out of } \\
\text { bundle, drink on empty stomach }\end{array}$ & Oral & Stomachache (Human) \\
\hline & & & & & $\begin{array}{l}\text { Decoction of leaves given to infants } \\
\text { under six months who are too small }\end{array}$ & Oral & Infant growth (Human) \\
\hline $\begin{array}{l}\text { Bersama abyssinica } \\
\text { subsp. abyssinica }\end{array}$ & Teberako & Melianthaceae & S & St & Stem peelings chewed & Oral & Dingetegna (Human) \\
\hline $\begin{array}{l}\text { Capsicum annuum/ } \\
\text { frutescens }\end{array}$ & $\begin{array}{l}\text { Berebere/ } \\
\text { Mitmitta }\end{array}$ & Solanaceae & $\mathrm{H}$ & Fr & Used as spice in food & Oral/ eaten & $\begin{array}{l}\text { Malaria; Swollen Lymph } \\
\text { Nodes; Stomachache } \\
\text { (Human) }\end{array}$ \\
\hline \multirow[b]{2}{*}{ Carica papaya } & \multirow[b]{2}{*}{ Papaya } & \multirow[b]{2}{*}{ Caricaceae } & \multirow[b]{2}{*}{$\mathrm{T}$} & \multirow[b]{2}{*}{ Sd } & Chew 7 seeds three times a day & Oral & Amoebic Dysentery (Human) \\
\hline & & & & & $\begin{array}{l}\text { Maceration of young leaves in cold } \\
\text { water }\end{array}$ & Oral & Abortion (Human) \\
\hline Citrus aurantifolia & Lome & Rutaceae & S & Fr & Drink fruit juice to stop vomiting & Oral & $\begin{array}{l}\text { (Anti-Emetic) Stops vomiting } \\
\text { (Human) }\end{array}$ \\
\hline Citrus medica & Turungo & Rutaceae & $\mathrm{S}$ & Fr & Fruit eaten for high blood pressure & Oral & $\begin{array}{l}\text { High Blood Pressure } \\
\text { (Human) }\end{array}$ \\
\hline \multirow{2}{*}{ Discopodium peninervum } & \multirow{2}{*}{ Rejicho } & \multirow{2}{*}{ Solanaceae } & \multirow{2}{*}{$\mathrm{S}$} & St & $\begin{array}{l}\text { Stem juice applied to wounds to stop } \\
\text { bleeding }\end{array}$ & Dermal & \multirow{2}{*}{ Stop bleeding (Human) } \\
\hline & & & & $\mathrm{L}$ & $\begin{array}{l}\text { Insert leaf into nose to stop nose } \\
\text { bleed }\end{array}$ & Nasal & \\
\hline \multirow[t]{2}{*}{ Ensete ventricosum } & \multirow[t]{2}{*}{ Wesse } & \multirow[t]{2}{*}{ Musaceae } & \multirow[t]{2}{*}{$\mathrm{H}$} & \multirow[t]{2}{*}{ St\&R } & Specific varieties eaten & Oral & $\begin{array}{l}\text { Bone Fractures, Aiding } \\
\text { Placental Discharge After } \\
\text { Birth, (Livestock) } \\
\text { Diarrhea, Inducing Abortion } \\
\text { and Wound Healing (Human) }\end{array}$ \\
\hline & & & & & $\begin{array}{l}\text { Bulla (made from liquid squeezed } \\
\text { from processing) drink as tonic }\end{array}$ & & $\begin{array}{l}\text { Strength and Improved } \\
\text { Immune Function (Human) }\end{array}$ \\
\hline Erythrina brucei & Welako & Fabaceae & $\mathrm{T}$ & St & Cold water maceration of stem & Oral & $\begin{array}{l}\text { Stimulate milk flow in cows; } \\
\text { treat coughing (Livestock) }\end{array}$ \\
\hline & & & & $\mathrm{L}$ & Chew leaves & & Stomach Problems (Human) \\
\hline & & & & Fr & Chew top part of fruit & Oral & Stomachache (Human) \\
\hline Eucalyptus globulus & Wajjo Barzafe & Myrtaceae & $\mathrm{T}$ & $\mathrm{L}$ & Rub leaves on skin to reduce fever & Dermal & Fever (Human) \\
\hline & & & & $\mathrm{L}$ & $\begin{array}{l}\text { Boil Eucalyptus and Damakasse in } \\
\text { water and the vapor inhaled }\end{array}$ & Nasal & Common Cold (Human) \\
\hline Foeniculum vulgare & Insilale & Apiaceae & $\mathrm{H}$ & $\mathrm{L}$ & $\begin{array}{l}\text { Added to soup } \\
\text { Chew }\end{array}$ & Oral & $\begin{array}{l}\text { Diuretic (Human) } \\
\text { Clean Stomach (Human) }\end{array}$ \\
\hline Hagenia abyssinica & So'icho & Rosaceae & $\mathrm{T}$ & $\mathrm{Fl}$ & Infusion of the female flowers & Oral & Tapeworms (Human) \\
\hline Linum usitatissimum & Shalala & Linaceae & $\mathrm{H}$ & Sd & $\begin{array}{l}\text { Seed soaked in water and drink for } \\
\text { gastritis }\end{array}$ & Oral & Gastritis (Human) \\
\hline Ocimum grattissimum & Damakese & Lamiaceae & $\mathrm{H}$ & $\mathrm{L}$ & Cold water maceration & Drink/Oral & $\begin{array}{l}\text { General Malaise } \\
\text { (Mitch) (Human) }\end{array}$ \\
\hline Peponium vogelii & Surupa & Cucurbitaceae & $\mathrm{H}$ & $\mathrm{Ft}$ & Chewing & Eaten/Oral & Stomach Trouble (Human) \\
\hline Persea americang & Abocato & Jauracene & $\mathrm{T}$ & Ft & Apply to Wound & Dermal & Cease bleeding (Human) \\
\hline Persea americana & & Lauracede & & $\Gamma t$ & Apply to Scalp & Topical & Dandruff \\
\hline
\end{tabular}




\begin{tabular}{|c|c|c|c|c|c|c|c|}
\hline Rhamnus prinoides & Ta'do & Rhamnaceae & $S$ & $\mathrm{~L}$ & $\begin{array}{l}\text { Mix } 7 \text { flowers of Yellow Aster with } \\
\text { young leaves of Tado chewed in a } \\
\text { quid wrapped with cloth or Enset } \\
\text { leaves. Juice swallowed for swollen } \\
\text { tonsils/lymph nodes }\end{array}$ & Oral & Swollen Tonsils/Lymph Nodes \\
\hline Rumex abyssinicus & Shishone & Polygonaceae & $\mathrm{H}$ & $\mathrm{R}$ & $\begin{array}{l}\text { Root decocted, drink or chewed for } \\
\text { Balaamo }\end{array}$ & Oral & Balaamo (Ibatch) (Human) \\
\hline Ruta chalepensis & Tenadame & Rutaceae & $\mathrm{H}$ & $\mathrm{L}$ & $\begin{array}{l}\text { Cold water maceration and drink to } \\
\text { relieve stomachache }\end{array}$ & Oral & Stomachache (Human) \\
\hline Schinus molle & Qundo & Anacardiaceae & $\mathrm{T}$ & Sd & Fruit chewed for sore throat & Oral & Sore Throat (Human) \\
\hline Vicia faba $\mathrm{L}$. & Baqella & Fabaceae & $\mathrm{H}$ & Sd & Raw seed chewed for gastritis & Oral & Gastritis (Human) \\
\hline
\end{tabular}

Table 4: The most Common Human and Livestock Diseases in Aleta Chuko Woreda.

\begin{tabular}{|c|c|c|c|c|}
\hline Disease Type & Disease name & Local Name & Frequency & Percentage \\
\hline \multirow{8}{*}{ Human } & Stomachache & Godowu Game & 13 & 16 \\
\hline & Headache & UmuDamume & 9 & 11.1 \\
\hline & Wound & Mada & 5 & 6.2 \\
\hline & Common Cold & Ganshu & 4 & 4.9 \\
\hline & Gastritis & Chogara & 3 & 3.7 \\
\hline & Toothache & HinkoteTiba & 3 & 3.7 \\
\hline & Skin Allergy & GoguTiba & 3 & 3.7 \\
\hline & Total & & 40 & 49.4 \\
\hline \multirow{4}{*}{ Livestock } & Cough & Busaano & 3 & 27.3 \\
\hline & Poor Milk Yield & Ado Fula Holtano & 3 & 27.3 \\
\hline & Stomachache & Godowu Game & 2 & 18.2 \\
\hline & Total & & 8 & 72.7 \\
\hline
\end{tabular}

Table 5: Preparation methods of Traditional Medicinal Plants.

\begin{tabular}{lcc}
\hline Preparation Methods & Frequency & Percentage (\%) \\
\hline Pounding and Crushing & 33 & 42.3 \\
Chewing & 15 & 19.2 \\
Squeezing & 11 & 14.1 \\
Maceration & 7 & 9.0 \\
Decoction & 7 & 9.0 \\
Powdering & 5 & $\mathbf{7 7}$
\end{tabular}

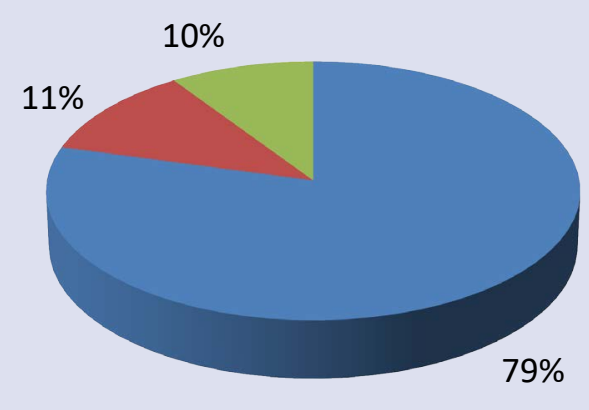

FOR HUMANS

FOR LIVESTOCK

FOR BOTH HUMANS

AND LIVESTOCKS

Figure 2: Percentage of the total plants used for treating human, livestock or both human and livestock ailments.

\section{Percentage and frequencies of used parts of the plants}

The results showed that the most dominant plant parts used during the preparation of curatives were leaves (49.2\%) followed by roots, fruits, and seeds (9.2\% each) (Figure 4). In agreement with the present study, several ethnobotanical investigations ${ }^{22,25,30,34,37-40}$, carried out in different parts of Ethiopia and elsewhere across the globe ${ }^{41,42}$, reported that leaves were the most utilized plant part in the preparation of remedies of plant origin. Whereas, studies found that roots were the most widely used plant parts in the preparation of traditional curatives..$^{27,32,43,44}$ ${ }^{29}$,indicated that the widespread usage of leaf in the preparation of remedies may possibly depict the comparative ease of harvesting/ collecting this plant part. Moreover, as to ${ }^{21}$, the preference of leaves over other plant parts could be attributable to the simplicity of remedial preparations compared to remedy preparations from roots, stem barks, whole plants and seeds. Accordingly, collecting leaves do not pose a greater danger to the existence of an individual plant as compared with the collection of roots, barks, stems or whole plants and hence do not 


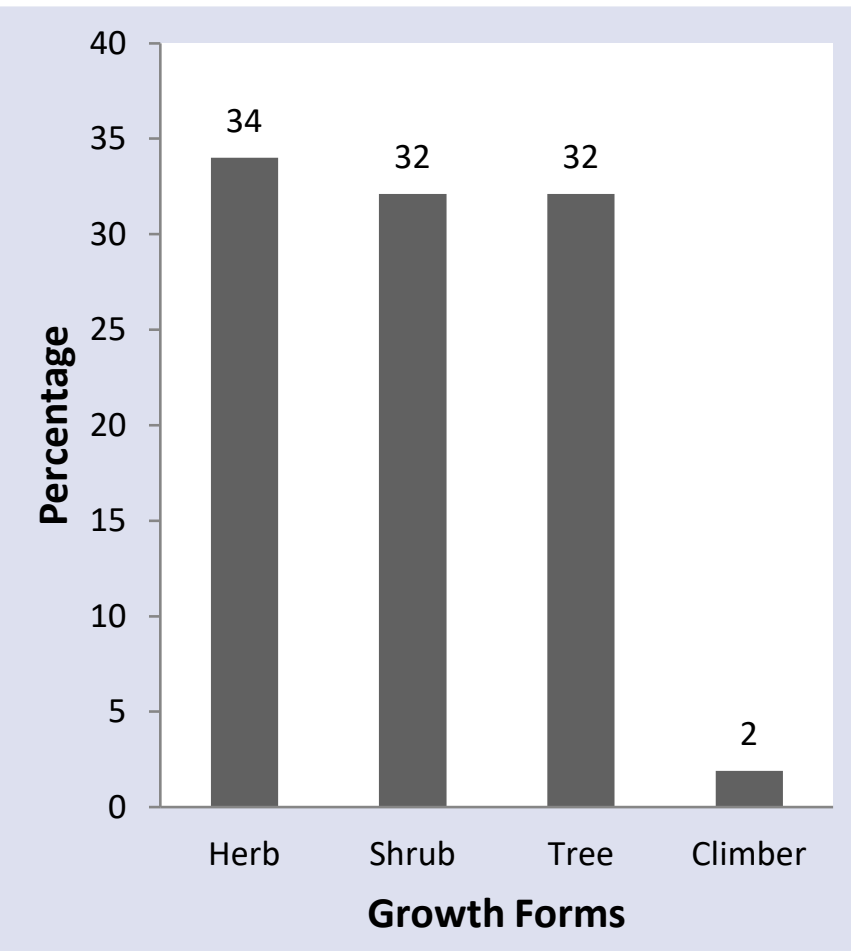

Figure 3: Percentage distribution of growth forms of medicinal plants used to treat human and livestock ailments.

affect sustainable utilization of the plants. ${ }^{30}$, pointed that the use of leaves than roots, barks, stems and whole plant minimize the threat to the destruction of medicinal plants. Stems, and flowers accounted for 7.7 and $4.6 \%$, respectively, while sap, leaf and seed each constituted for $3.1 \%$ of the total preparations. The bark, bulb, and a combination of stem and root contributed for the remaining fraction (4.5\%) of the preparation of the therapeutics (Figure 4).

\section{Modes of preparation of medicinal plants}

According to the informants of the study area, medicinal plants were formulated in the fresh forms $66 \%$ while $18 \%$ were prepared after drying. On the other hand, $16 \%$ of the remedies were reported to be used in either fresh or dry forms to treat human and livestock ailments. In agreement with the present study, similar studies $29,30,34,33,37,39$, reported in their ethnobotanical investigation that high proportions of the respective medicinal plants were used in fresh form during curative preparations. In a line with ${ }^{29}$, the common use of freshly processed remedies may signify the availability of comparatively good stock of plant materials in the study area that could be collected whenever the need arises. ${ }^{30}$, reported that widely held belief by local people that fresh materials are efficacious in treatment over their dry counterparts as the active ingredients. Similarly ${ }^{29}$, suggested that the frequent use of fresh materials could proceed from an effort not to lose volatile oils, the concentration of which could deteriorate during drying.

\section{Methods of preparations of remedies from medicinal} plants: Frequency and percentages

The dominant methods of preparations were pounding and crushing (42.3\%) followed by chewing (19.2\%) and squeezing (14.1\%) for the treatment of various diseases affecting humans and their stock in the study area. On the other hand, principally powdering (6.5\%) but also maceration and decoction (each with 9\%), were the least employed method during preparation of the curatives from medicinal plants (Table 5). Similar findings about crushing and pounding as the predominant method of medicinal preparations were also reported by. ${ }^{34,37}$ Apart from this ${ }^{38}$, indicated that the principal methods of remedy preparation were crushing $(37.31 \%)$, squeezing $(29.85 \%)$ and powdering $(16.42 \%)$ of the various parts of medicinal plants.

\section{Dosage measurement of medicinal preparations}

In Aleta Chuko Woreda, traditional medicine practitioners employ various measurement units and durations to determine the dosage of curatives. The amounts of remedy and prescription rates were generally dependent on the degree and duration of the ailments. The data obtained from respondents revealed that traditional medicines dosage were employed by various units of measurement like numbers (e.g. for leaves, seeds and fruits), pinch (e.g. for powdered plant parts) and finger length (e.g. for root, root bark, stem and stem bark) to estimate and fix the measured quantity of the medicine which depends on the perception of healers/herbalists. Similar findings pertaining to the traditional medicinal dosage were reported by..$^{25,33,45,46}$ In congruence with similar studies ${ }^{25,27}$, most of the medicinal plant preparations given did not have standardized doses. Accordingly, in most cases dosages were determined according to the age and physical appearance of the patient, sociocultural explanation of the illness, diagnosis and experience of individual traditional medicine practitioner..$^{45}$

\section{Routes of applications/administration of the plant remedies}

The results of the study revealed that oral application (70.5\%) was the most widely used route of administration followed by dermal or topical (20.5\%), and nasal (7.7\%) routes (Figure 5). The present findings is in accordance with study of. ${ }^{37}$ The reason for the dominance of oral application of remedies may be due to it is painless and unproblematic way of taking the medicines. On the other hand, ocular route accounted only for about a percent of the total reported administration route. Likewise $^{45}$, found that ocular application of traditional remedies was the least (accounting only for $2.1 \%$ ) of all employed administration routes.

\section{Relationships between the ages of informants and their knowledge of traditional medicinal plants}

Pearson Correlation analysis revealed that age of informants and the knowledge of traditional medicinal plants were positively correlated, $r=0.74812$ (Figure 6). Thus, elderly people have more knowledge of traditional medicine and traditional medicinal plant species than the youngsters. In agreement with the present study, various studies ${ }^{25,33,45,46}$, reported that as people become older and older their knowledge of traditional medicine would essentially become better and better. On the other hand, the relatively lower medicinal plant knowledge exhibited by the more youthful segment of the community could stem from the relative difficulty in its transfer from the elders to the young generation. ${ }^{23}$

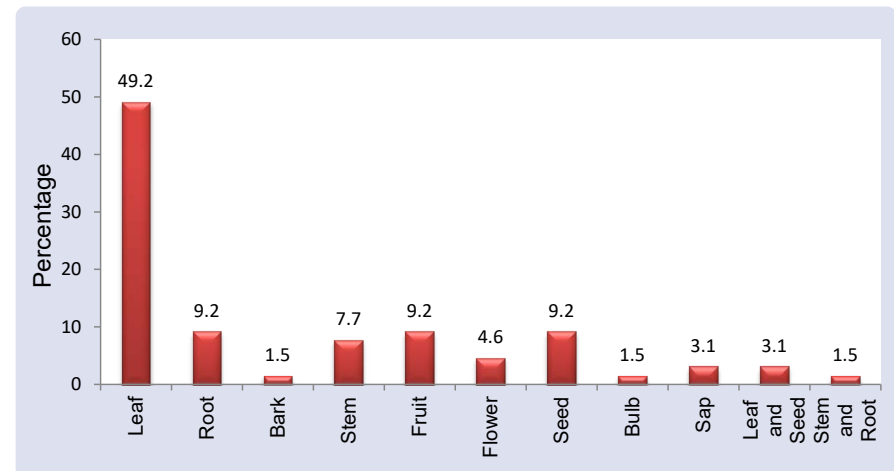

Figure 4: Percentage distribution of plant parts used in preparation of therapeutics for human and livestock diseases. 


\section{Relationships between the educational levels of informants and their knowledge of traditional medicinal plants}

In order to assess the relationship between educational background of respondents and the number of medicinal plants they have managed to report, Pearson Correlation was carried out (Figure 7). Accordingly, there is a negative correlation between educational background and traditional knowledge of medicinal plants of the study area $(\mathrm{r}=$ 0.87029). ${ }^{47}$ also reported that there is a negative relationship between the educational level of informants and their ethnobotanic knowledge.

\section{CONCLUSION}

The present study was conducted in selected Kebeles of Aleta Chuko Woreda in order to assess the indigenous knowledge that equips the community to identify the medicinal plants, formulate the medicines and subsequently administer the curatives used to treat various human

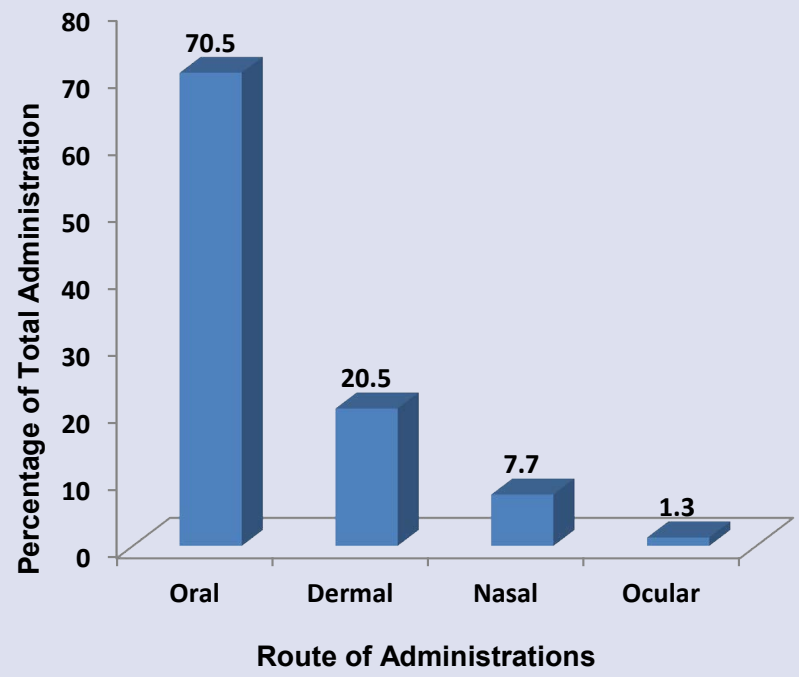

Figure 5: Routes of administration and percentages.

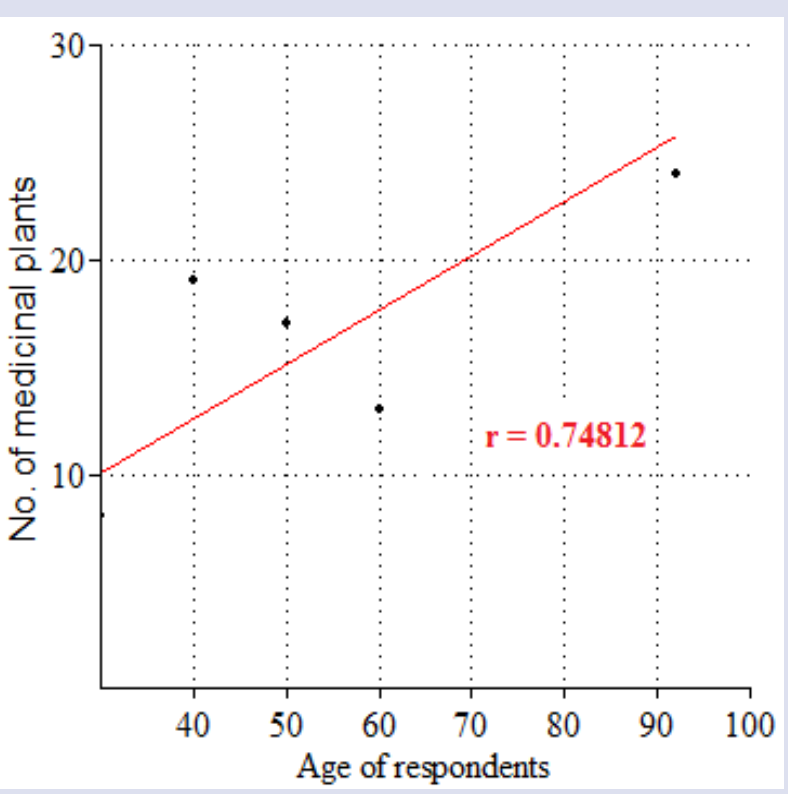

Figure 6: Age of respondents versus number of medicinal plants collected in the Aleta Chuko Woreda.

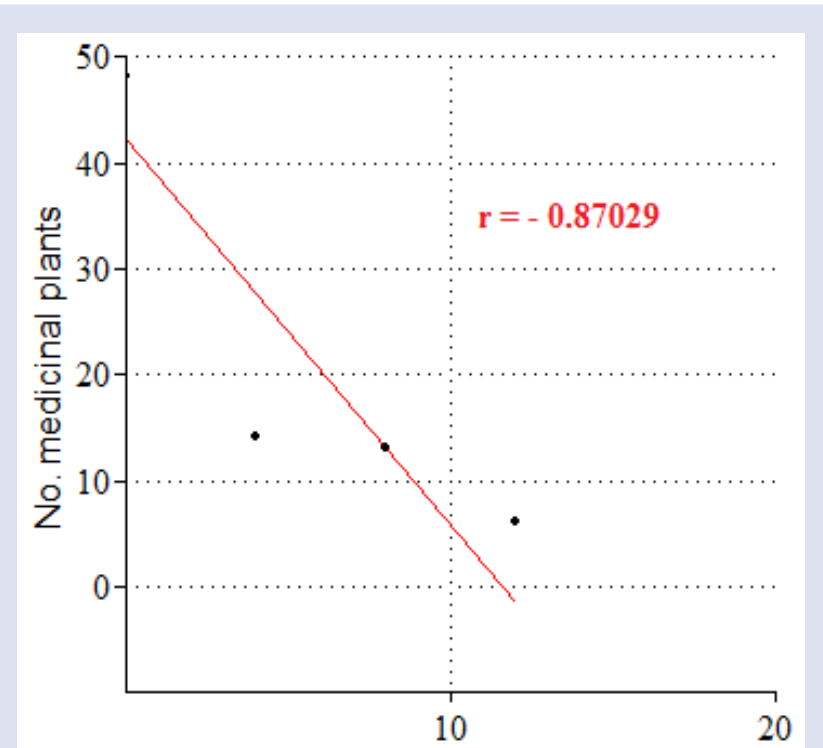

Educational level of respondents

Figure 7: The association between number of medicinal plants identified and Educational level of respondents in Aleta Chuko Woreda.

and livestock diseases, as well as to characterize the threats that the medicinal plants are facing in the study area. The study revealed that the Aleta Chuko community observably used traditional medicine to treat both human and livestock diseases.

A total of 53 wild and cultivated medicinal plant species which are herbs, shrub and tree species distributed into 30 families and 49 genera. Lamiaceae (8) followed by Rutaceae (5), and Asteraceae (4) were the predominant families observed. 79,11 , and $10 \%$ of the total species were used for treating humans, livestock, and both humans and livestock diseases, respectively. The most common diseases affecting humans and animals were stomachache and cough, in that order. Sixty percent of the medicinal plants were collected from the wild while the $40 \%$ of the same were harvested from home gardens. Herbs constituted the highest fraction (34\%) of the total species and the most commonly used plant parts during the preparation of remedies were leaves. Freshly harvested plant materials are mostly used in the preparation of remedies which show about the availability of plant materials in the vicinity.

Our study recommends that the attention should be given to the standardization of the unit measurement, antidotes and cleanliness of these medicines prepared from plants by improving the traditional medicines and creating awareness among the younger members of the community on the importance and conservation of traditional medicinal plant species and the associated indigenous knowledge which is the need of the hour. Finally, further scientific investigations are to be initiated for the isolation of the bioactive principles from those traditional medicinal plant species reported to be the most effective way to treat the most common health problems of the study area.

\section{ACKNOWLEDGMENTS}

The authors' sincere thanks go to Arba Minch University for provision of the opportunity to conduct the research. Authors also like to express their gratitude for Aleto Chuko Woreda people and staffs for their cooperation in providing basic information.

\section{AUTHOR CONTRIBUTIONS}

TG and BC conceived and designed the study. TG analyzed the data. TG and $\mathrm{BC}$ contributed to the writing of the manuscript. TG and $\mathrm{BC}$ 
agree with manuscript results, conclusions and developed the structure and arguments for the article. Both authors reviewed and approved the final manuscript.

\section{DECLARATION OF CONFLICTING INTERESTS}

The authors declare there are no competing interests.

\section{FUNDING}

The source of funding for this research was Research Coordination Office, College of Natural Sciences, Department of biology, Arba Minch University, Arba Minch, South Ethiopia. The role of the funding body was making the fund available to the researchers but it did not have role in the design of the study and collection, analysis, and interpretation of data and in writing the manuscript.

\section{REFERENCES}

1. Cotton CM. Ethnobotany: Principles and Applications. John Wiley and Sons, London. 1996.

2. Martin GJ. Ethnobotany: A method Manual. Chapman and Hall, London. p. 251; 1995.

3. Balick, MJ, Cox, PAR. Plants People and Culture. The science of ethnobotany Scientific American Library, New York, USA. 1996.

4. Nyamwaya D. Africa Indigenous medicine: An anthropological prospective for policy makers and primary health care managers. AMREF, Nairobi. 1992.

5. Ngono NRA, Koanga MML, Tchinda TA, Magnifouet NH, Motso CR, Mballa BZ, et al.,. Ethnobotanical survey of some Cameroonian plants used for treatment of viral diseases. Afr J Plant Sci. 2011; 5(1): 15-21.

6. Fekadu F. Ethiopian Traditional Medicine: Common Medicinal Plants in Perspective, Califormia, U.S.A: SAGE Publications. 2007;163

7. WHO. General Guidelines for Methodologies on Research and Evaluation of Traditional Medicine. Switzerland: Geneva, p 1-80; 2000.

8. Gbadamosi IT, Egunyomi A. Ethnobotanical survey of plants used for the treatment and management of sexually transmitted infections in Ibadan, Nigeria. Ethnobotany Res Applications. 2014; 12:659-669.

9. Yirga G. Assessment of traditional medicinal plants in Endrta District, South-eastern Tigray, Northern Ethiopia. Afr J Plant Science. 2010; 4(7): 255-260.

10. ACWARDO. Aleta Chuko Woreda Agricultural and Rural Development Office (ACWARDO). Annual report of the sector, Chuko, Aleta Chuko Woreda, Sidama Zone, SNNPRS, Ethiopia 2015.

11. ECSA. Ethiopian Central Statistics Authority. National Population and Housing Census of Ethiopia. Addis Ababa, Ethiopia. 2014.

12. Hedberg I, Edwards S. Flora of Ethiopia and Eritrea. Volume 3,Pittosoraceae to Araliaceae. The National Herbarium Addis Ababa University, Addis Ababa and Uppsala, 1989; pp. 659.

13. Phillips S. Poaceae (Graminaceae). In: Hedberg, I. and Edwards, S. (eds.), Flora of Ethiopia and Eritrea, Vol.7. The National Herbarium, Addis Ababa University, Addis Ababa and Uppsala. 1995; p 420.

14. Edwards S, Tadesse M, Hedberg I. Flora of Ethiopia and Eritrea: Canellaceae to Euphorbiaceae, Vol. 2 (2).The National Herbarium, Addis Ababa University, Addis Ababa and Uppsala. 1995.

15. Edwards S, Demissew S Hedberg I. Flora of Ethiopia and Eritrea: Hydrocharitaceae to Arecaceae, Vol. 6. The National Herbarium, Addis Ababa University, Addis Ababa and Uppsala. 1997.

16. Edwards S, Tadesse M, Demissew S. Flora of Ethiopia and Eritrea: Magnoliaceae to Flacourtiaceae, Vol. 2 (1). The National Herbarium, Addis Ababa University, Addis Ababa and Uppsala. 2000.
17. Hedberg I, Edwards S, Nemomissa S. Flora of Ethiopia and Eritrea: Apiaceae to Dipsaceae. Vol. 4(1), The National Herbarium, Addis Ababa University, Addis Ababa and Uppsala. 2003.

18. Hedberg I, Kelbessa E, Edwards S, Demissew S, Persson E. Flora of Ethiopia and Eritrea: Gentianaceae to Cyclocheilaceae. Vol 5, The National Herbarium, Addis Ababa and Uppsala. p.690; 2006.

19. Hedberg I, Friis IB, Persson E. Flora of Ethiopia and Eritrea. General part and Index to volumes 1-7. Vol 8, Addis Ababa, Ethiopia and Uppsala, p 331; 2009.

20. Tadesse M. Asteraceae (Compositae).In: Hedberg I. Friss I, Edwards S. (eds.), Flora of Ethiopia and Eritrea Vol.4 (2). The National Herbarium, Addis Ababa University, Addis Ababa and Uppsala. 2004.

21. Tolassa E. Use and Conservation of Traditional Medicinal Plants by indigenous people in Gimbi Woreda, Western Wellega. M.Sc. Thesis, Addis Ababa University, Ethiopia. 2007.

22. Tamene S. An Ethnobotanical Study of Medicinal Plants in Wondo Genet Natural Forest and Adjacent Kebeles, Sidama Zone, SNNPRS, Ethiopia. M.Sc. Thesis. Addis Ababa University. 2011.

23. Hailemariam T, Demissew S, Asfaw Z. An ethnobotanical study of medicinal plants used by local people in the lowlands of Konta Special Woreda, southern nations, nationalities and peoples regional state, Ethiopia. J Ethnobiol Ethnomed. 2009; 5:1-26.

24. Berhane K, van Andel T, Josephus L, vander Maesen G, Asfaw Z. 2014. Use and Management of Traditional Medicinal Plants by Maale and Ari Ethnic Communities in Southern Ethiopia. J Ethnobio Ethnomed. 2014; 10:46.

25. Regassa R. Assessment of indigenous knowledge of medicinal plant practice and mode of service delivery in Hawassa city, southern Ethiopia. J Medicinal Plants Res. 2013; 7(9): 517-535.

26. Adefa M, Abraha B. Ethnobotanical survey of traditional medicinal plants in Tehuledere district, South Wollo, Ethiopia. J Medicinal Plants Res. 2011; 5(26): 6233-6242.

27. Luleka E, Kelbessa E, Bekele Tand Yineger H. An Ethnobotanical Study of Medicinal Plants in Mana Angetu District, Southeast Ethiopia. J Ethnobiol Ethnomed. 2008; 4(10): 4-10.

28. Giday M, Asfaw Z, Woldu Z, Teklehaymanot T. (2009). Medicinal plant knowledge of the Bench ethnic group of Ethiopia: an ethnobotanical investigation. Journal of Ethnobio and Ethnomed. 2009; 5(34):1-35.

29. Yirga G. Ethnobotanical study of medicinal plants in and around Alamata, Southern Tigray, Northern Ethiopia. Current Res J Biological Sci. 2010; 2(5):338-344.

30. Andarge $\mathrm{E}$, Shonga $\mathrm{A}$, Agize $\mathrm{M}$ and Tora A. Utilization and Conservation of Medicinal Plants and their Associated Indigenous Knowledge (IK) in Dawuro Zone: An Ethnobotanical Approach. International J Medicinal Plant Res. 2015; 4(3): 330-337.

31. Alemayehu G, Asfaw Z, Kelbessa E. Ethnobotanical Study of Medicinal Plants Used by Local Communities of Minjar-Shenkora District, North Shewa Zone of Amhara Region, Ethiopia. J Medicinal Plants Studies. 2015; 3(6):1-11.

32. Mesfin F, Demissew S, Teklehaymanot T. An Ethnobotanical study of medicinal plants in Wonago Woreda, SNNPR, Ethiopia. J Ethnobiol Ethnomed, 2009; 5(28): 1-18.

33. Lulekal E, Asfaw Z, Kelbessa E and VanDamme P. 2014 Ethnoveterinary Plants of Ankober District, North Shewa Zone, Amhara Region, Ethiopia. J Ethnobiol Ethnomed. 2014; 10: 21-29.

34. Addisie Y, Yared D, Ashok KP, Tomas Z, Awol A. Traditional medicinal plants used by people in Libo-Kemkem District, South Gondar, Ethiopia. Asian J Agricul Sci. 2012; 4(3): 1

35. Abera B. Medicinal plants used in traditional medicine by Oromo people, Ghimbi District, Southwest Ethiopia. Journal of Ethnobio Ethnomed. 2014; 10:40. 
36. Giday M. An Ethnobotanical study of medicinal plants used by the Zay People in Ethiopia. CBM: Slentserie, 2001; 3:81-99.

37. Gebrehiwot M. An Ethnobotanical Study of Medicinal Plants in SeruWereda, Arsi Zone of Oromia Region, Ethiopia. M.Sc. Thesis. Addis Ababa University, Ethiopia. 2010

38. Yineger $\mathrm{H}$, Yewhalaw $\mathrm{D}$. Traditional medicinal plant knowledge and use by local healers in Sekoru District, Jimma Zone, Southwestern Ethiopia. J Ethnobiol and Ethnomed. 2007; 3(24): 1-7.

39. Yirga G. Use of traditional medicinal plants by indigenous people in Mekele town, capital city of Tigray regional state of Ethiopia. $J$ Medicinal Plants Res. 2010; 4(17): 1799-1804.

40. Zerabruk S, Yirga G. Traditional knowledge of medicinal plants in Gindeberet district, Western Ethiopia. South Afr J Botany. 2011; 2:1-5.

41. Grace NN, Rainer BW, Barbara G, Eric NL, Ngumi VW. Utilization of weedy species as source of traditional medicines in central Kenya. Lyonia. 2004; 7:71-87.

42. Musa S, Fathelrhman E, Elsheikh A, Lubna A, Abdel L E, Sakina M. Ethnobotanical study of medicinal plants in the Blue Nile State, Southeastern Sudan. J Medicinal Plants Res. 2011; 5(17): 4287-4297.
43. Hunde D, Asfaw Z, Kelbessa E. 2004. Use and management of ethnoveterinary medicinal plants by indigenous people in 'Boosat', Wolench. Ethiopian J Biol Sci. 2004; 3(2):113-132.

44. Balemie K, Kebebew F. Ethnobotanical study of wild edible plants in Derashe and Kucha Districts, South Ethiopia. J Ethnobiol Ethnomed. 2006; 2:53.

45. Teklehaymanot T, Giday M. Ethnobotanical study of medicinal plants used by people in Zegie Peninsula, Northwestern Ethiopia, $\mathrm{J}$ Ethnobiol Ethnomed. 2007; 3(1): 1-11.

46. Assefa A, Abebe T. Ethnobotanical study of wild medicinal trees and shrubs in Benna Tsemay District, Southern Ethiopia. J Sci Dev. 2014;2:1.

47. Awas T, Demissew S. Ethnobotanical study of medicinal plants in Kafficho people, southwestern Ethiopia. In: Proceedings of the 16th International Conference of Ethiopian Studies, ed. by SveinEge, Harald Aspen, BirhanuTeferra and Shiferaw Bekele, Trondheim, 2009; 711-726. 


\section{GRAPHICAL ABSTRACT}

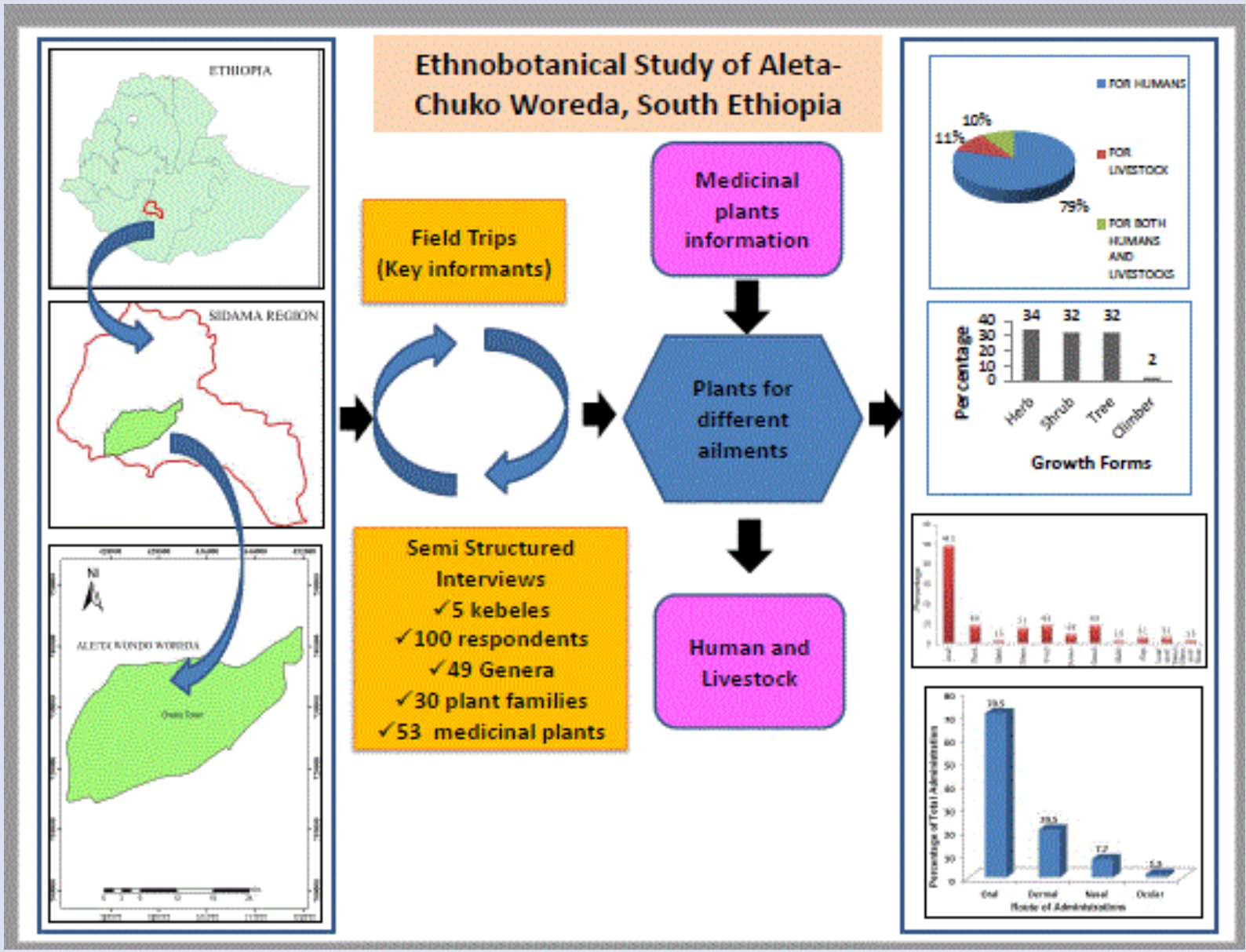

\section{ABOUT AUTHORS}

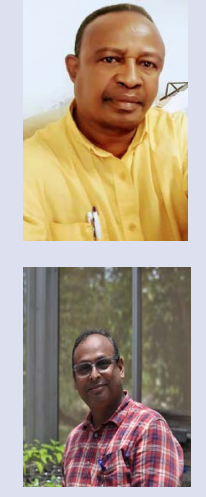

Dr. Tizazu Gebre Alemayehu, got Master's degree from Addis Ababa University and Doctorate from Addis Ababa University, Arba Minch University and University of California, Santa Cruz under Sandwich Programme in Plant Biology and Biodiversity Management, Landscape Ecology. Present he is working as Assistant Professor in Department of Biology, Arba Minch University and also Research Director for College of Natural Sciences, Arba Minch University, Ethiopia.

Dr. Chinthapalli Bhaskar Rao, got Masters, Mphill and Doctorate degree from University of Hyderabad, a Central University, Hyderabad, India in Molecular Plant Physiologist and Plant Biology. Worked as Postdoctoral fellow in University of Missouri, Columbia, USA., and Assistant and Associate Professor in College of Natural Sciences, Department of Biology, Arba Minch University, Ethiopia. Present he is working as Senior Lecture, Department of Life Sciences, Faculty of Science and Technology, University of West Indies, Mona, Kingston, Jamaica.

Cite this article: Gebre T, Chinthapalli B. Ethnobotanical Study of the Traditional Use and maintenance of Medicinal Plants by the People of Aleta-Chuko Woreda, South Ethiopia. Pharmacogn J. 2021;13(5): 1097-1108. 